\title{
MYXOBOLUS INFECTION IN THE CORNEA OF THE ROACH (RUTILUS RUTILUS) IN LAKE BALATON
}

\author{
Réka BORZÁK, Kálmán MoLNÁR, Gábor CECH and Csaba SzÉKELY* \\ Institute for Veterinary Medical Research, Centre for Agricultural Research, \\ Hungarian Academy of Sciences, Hungária krt. 21, H-1143 Budapest, Hungary
}

(Received 2 February 2018; accepted 16 April 2018)

\begin{abstract}
Infection of the cornea in fishes by Myxobolus plasmodia is a common but still little known site preference of myxosporeans. A sporadic but striking infection in the cornea of the roach (Rutilus rutilus) was observed in Lake Balaton, Hungary. Relatively small, round plasmodia 250 to $500 \mu \mathrm{m}$ in diameter developed in the dense connective tissue of the cornea. Morphological and molecular biological examination of spores collected from cysts in the cornea demonstrated that this infection is caused by Myxobolus fundamentalis, a species hitherto reported only from the cartilaginous gill arch of the roach. The 18S rDNA sequences of spores from the cornea showed $99.9 \%$ identity to the sequences of spores from the gill arch, and they also shared $99.9 \%$ identity with the sequences of triactinomyxon actinospores obtained from the oligochaete Isochaetides michaelseni.
\end{abstract}

Key words: Myxozoa, plasmodia, eye, cornea, site selection, roach, Lake Balaton, Hungary

The roach (Rutilus rutilus L.) is one of the most common cyprinid fishes in the Northern part of Eurasia. Its Myxobolus fauna is well studied. So far, 14 species (M. alievi Gasimagomedov, 1970; M. chernovae Landsberg \& Lom, 1991; M. cycloides Gurley, 1893; M. diversicapsularis Slukhai, 1984; M. dujardini Thélohan, 1892; M. elegans Kashkovski, 1966; M. feisti Molnár et al., 2008; M. fundamentalis Molnár et al., 2010; M. intimus Zaika, 1984; M. marginatus Kulemina, 1969; M. mucosus Liu et al., 2016; M. pseudodispar Gorbunova, 1936; M. rutili Donec \& Tozyyakova, 1984; M. sommervillae Molnár et al., 2010; M. wootteni Molnár et al., 2010) have been reported to cause infections in various organs of this fish species (Eiras et al., 2005, 2014; Liu et al., 2016). Most species are specific to the roach and infect a specific tissue and organ (Molnár et al., 2010; Molnár and Eszterbauer, 2015). However, little is known about Myxobolus infection of the eyes. The best studied myxosporean known to infect the eyes is Thelohanellus oculileucisci developing in the vitreous humour of the eyes of roach (Trojan, 1909; Lom et al., 1987), but there are also Myxobolus spp. known to form small plasmodia in the cornea and sclera of various cy-

${ }^{*}$ Corresponding author; E-mail: szekely.csaba@agrar.mta.hu; Phone: 0036 (1) 467-4065 
prinid, centrarchid and percid fishes, like M. heterolepis in Notropis heterolepis Li \& Desser, 1985, M. corneus Cone et al., 1990 in Lepomis macrorchirus, M. magnus Awerinzev, 1913 in Gymnocephalus cernua, M. volgensis Reuss, 1906 in Sander lucioperca, and M. scleroperca Guilford, 1963 in Perca flavescens (Reuss, 1906; Awerinzew, 1913; Li and Desser, 1985; Cone et al., 1990; Muzzal, 1995). El-Mansy (2005) reported a common infection of the cornea of three tilapian fishes by M. heterosporus Baker, 1963 in Egypt. Similar infections by Myxobolus spp. have been published from India, where Hemananda et al. (2009) found M. clariae Hemananda et al., 2009 and M. utlouensis Hemananda et al., 2009 infecting the cornea of the freshwater fish Clarias batrachus L. Moreover, another myxosporean species, Henneguya intracornea caused a similar infection in the characid fish Astyanax scabripinis Jenyns (Gioia et al., 1986).

In this paper we report a myxosporean infection in the eye of roach in Lake Balaton, where small plasmodia of a Myxobolus sp. (Fig. 1) were found in the dense connective tissue of the cornea. Molecular studies done on the $18 \mathrm{~S}$ rDNA sequences of spores proved that this species shared $99.9 \%$ identity with M. fundamentalis hitherto known only from the gill arch of the roach.

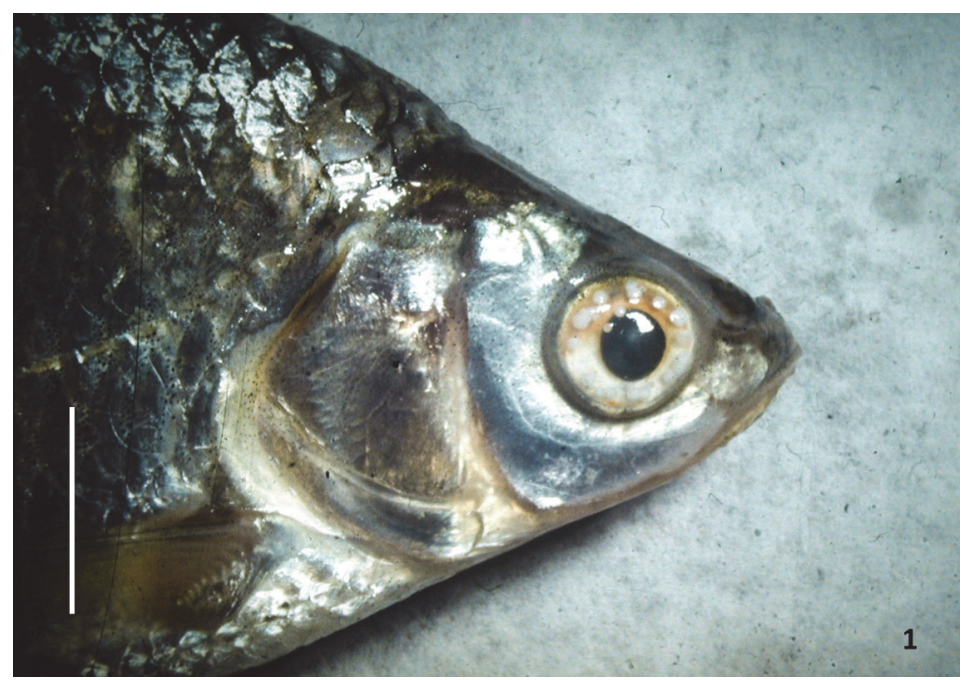

Fig. 1. Eye of a roach infected by small plasmodia of Myxobolus fundamentalis. Fresh mount. (Photograph by Dr György Csaba). Bar $=1.5 \mathrm{~cm}$

\section{Materials and methods}

During regular studies on myxosporean infections of Lake Balaton fishes (Molnár and Székely, 1999; Molnár, 2000; Molnár et al., 2010), unreported observations were made on white spots located on the eyes of roach which were 
supposed to be myxosporean plasmodia. After receiving a convincing picture from Dr György Csaba, a colleague in the Central Veterinary Institute, a survey was initiated in Lake Balaton in 2012-2013, and a total of 230 roach specimens (size: 9 to $16 \mathrm{~cm}$ ) from Lake Balaton were examined for this infection in three

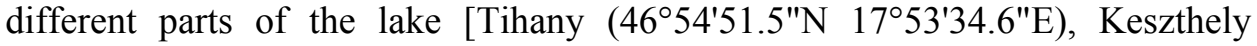
$\left(46^{\circ} 45^{\prime} 15.3^{\prime \prime} \mathrm{N} 17^{\circ} 14^{\prime} 56.5^{\prime \prime} \mathrm{E}\right)$ and Balatonszemes (46 $\left.\left.48^{\prime} 36.4^{\prime \prime} \mathrm{N} 17^{\circ} 45^{\prime} 55.9^{\prime \prime} \mathrm{E}\right)\right]$. In the framework of a new project in August 2017, targeted investigations were carried out, when 47 specimens of roach were collected from the south-western part of Lake Balaton [Balatonberény (46 $\left.42^{\prime} 54.7^{\prime \prime} \mathrm{N} 17^{\circ} 19^{\prime} 12.6^{\prime \prime} \mathrm{E}\right)$ and Balatonboglár $\left.\left(46^{\circ} 46^{\prime} 41.4^{\prime \prime} \mathrm{N} 17^{\circ} 38^{\prime} 37.1^{\prime \prime E}\right)\right]$. Moreover, each year several dozen specimens of other fish species commonly inhabiting Lake Balaton (Cyprinus carpio, Abramis brama, Blicca bjoerkna, Pelecus cultratus, Scardinius erythrophthalmus, Alburnus alburnus, Aspius aspius, Esox lucius, Sander lucioperca, Anguilla anguilla) were also submitted for health checks. The cornea of live fish specimens was examined with a loupe at the catchment site. The infected specimens were carried to the laboratory alive, in oxygenated plastic bags, and kept in aerated aquaria. Before extermination by a cervical cut, fish were sedated by a drop of clove oil into their water. In roach samples collected in 2017 the plasmodia from the infected eyes were separated, the spores inside them were divided equally for morphological analysis such as measuring, microscopic and histological studies, and preserved in $70 \%$ ethanol for molecular analysis. Morphological studies on the spores and histological procedures were performed as described by Molnár et al. (2010).

For molecular studies, DNA was extracted from the spores of single plasmodia (all isolated from different fish specimens) preserved in ethanol using the DNeasy Blood \& Tissue Kit (Qiagen, Hilden, Germany). The samples were centrifuged at 10,000 rpm for $10 \mathrm{~min}$ and the supernatant was removed. Spore pellets were treated according to the manufacturer's instructions, and $100 \mu \mathrm{l}$ of DNA was extracted at the final elution step. Amplification and sequencing of the 18S rDNA were conducted as described by Cech et al. (2015).

Sequence fragments were assembled using MEGA V6.06 (Tamura et al., 2013) and ambiguous bases clarified using corresponding ABI chromatograms. Nucleotide sequences and reference sequences from GenBank based on BLAST matches were aligned with the software CLUSTAL W (Thompson et al., 1994). DNA pairwise distances were calculated with MEGA V6.06 software using the Maximum Composite Likelihood model. Phylogenetic analysis was performed via Maximum Likelihood (ML); Myxobolus cerebralis Hofer, 1903 was chosen as the outgroup. The dataset was tested using MEGA V6.06 for the nucleotide substitution model of best-fit and the model shown by the Akaike Information Criterion (AIC) as the best-fitting one was chosen (GTR+G+I model). Bootstrap values were generated based on 1,000 resampled datasets. 


\section{Results}

Of the different fish species surveyed for parasite infection of the eye, Myxobolus plasmodia were found only in roach. During the first examination period only three out of the 230 fish specimens were infected with altogether 5 plasmodia. These infected roach specimens (10-12 cm long) were collected in different seasons (April, September and November) and at different sites of the Lake. However, during the targeted investigation period in 2017, 3 out of the 20 roach specimens (15\%) originating from Balatonberény and 6 out of the 27 roach specimens $(22 \%)$ derived from Balatonboglár proved to be infected with 1 to 7 plasmodia. Infected fishes were found both in the smaller-size group of 9-12 cm $(1+$ year old) and among larger fishes of 14-16 cm body length $(2+$ and $3+$ years old age classes). Plasmodia were seen with a hand loupe both in the centre and at the periphery of the pupillary region (Figs 1 and 2). They seemed to be located at the surface of the cornea as lens-shaped cysts; however, the examination of histological sections revealed that the plasmodia were located deep in the multilayered dense connective tissue of the cornea, had a globe shape and were 250 to $500 \mu \mathrm{m}$ in diameter (Fig. 3). All the plasmodia found had mature spores inside (Fig. 4). The shape and measurements of the spores collected from plasmodia corresponded to M. fundamentalis Molnár et al., 2010.

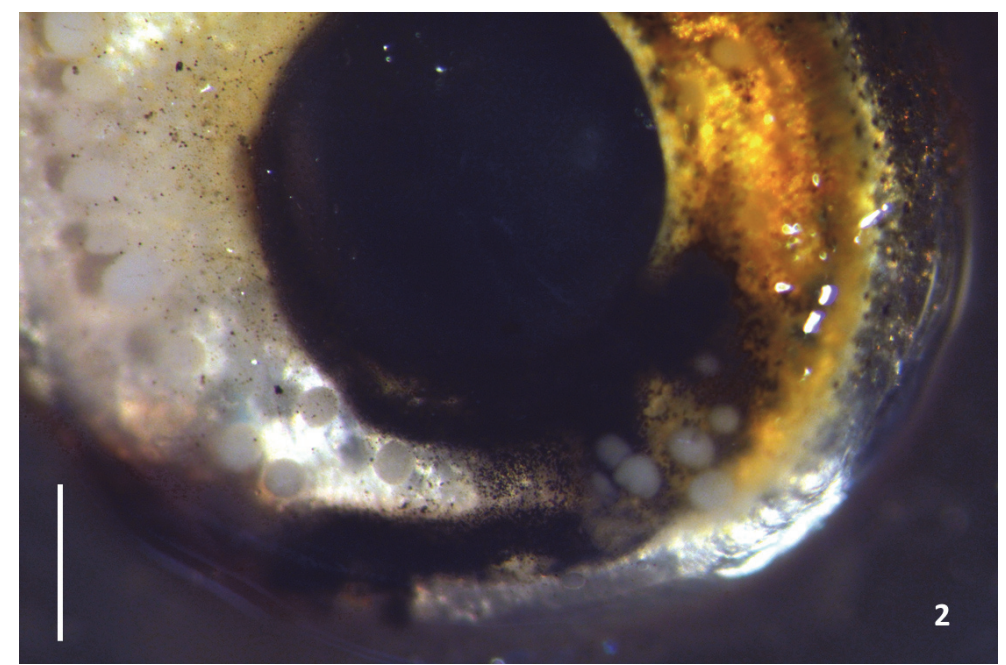

Fig. 2. Eye of a roach collected in 2017, infected by small plasmodia of Myxobolus fundamentalis. Fresh mount. Bar $=1 \mathrm{~mm}$

More than $1625 \mathrm{bp}$ was amplified from the 18S rRNA gene from two spore samples, which showed $100 \%$ identity to each other, shared $99.9 \%$ identity with the above-mentioned $M$. fundamentalis originating from the connective tis- 
sue of the gill arch of roach (GU968200) and also had 99.9\% identity with the $18 \mathrm{~S}$ rDNA sequences from Triactinomyxon type 1 actinospores obtained from the oligochaete Isochaetides michaelseni (Székely et al., 2014) (Fig. 5).

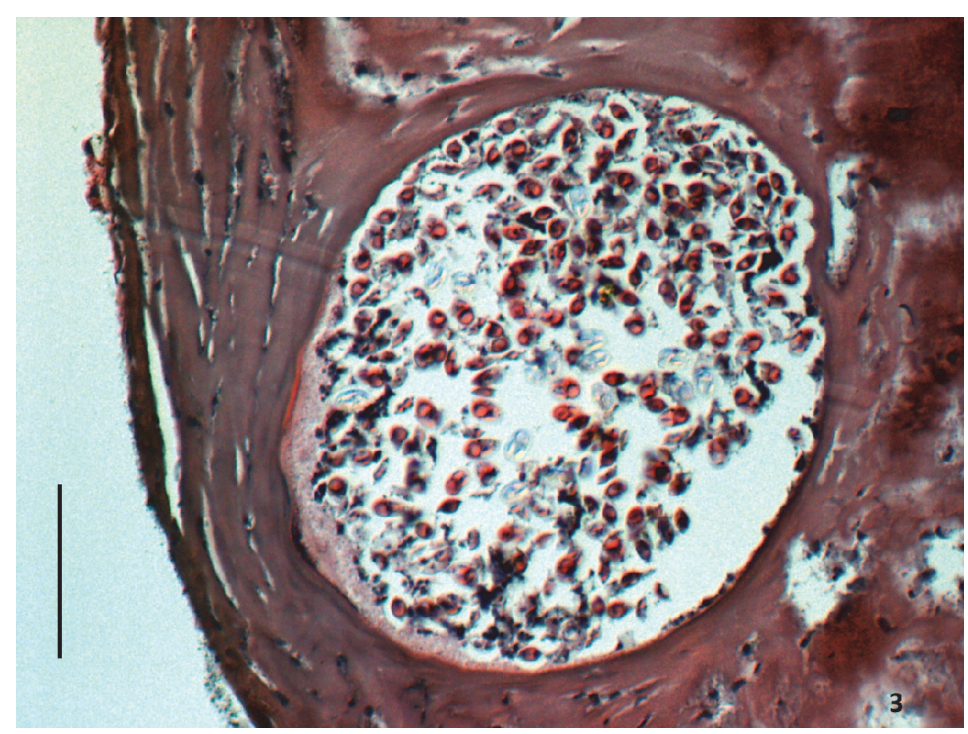

Fig. 3. A plasmodium of Myxobolus fundamentalis in the dense connective tissue of the cornea. The damaged epithelium is mostly desquamated. Haematoxylin and eosin (HE) staining. $\mathrm{Bar}=50 \mu \mathrm{m}$

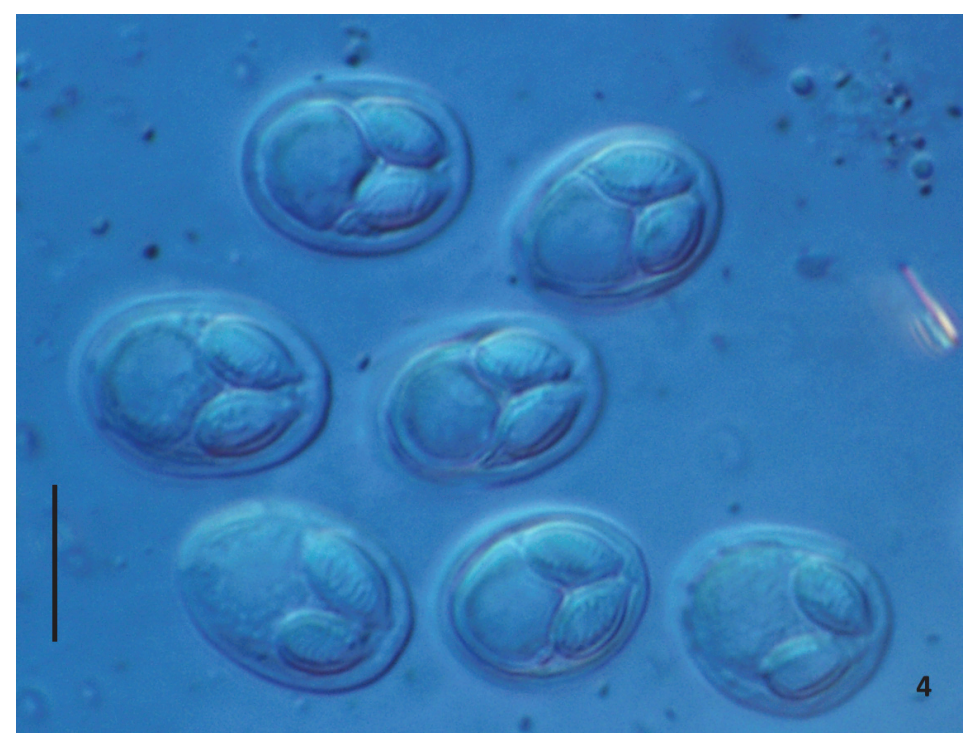

Fig. 4. Spores of Myxobolus fundamentalis from a corneal plasmodium. Wet mount. $\mathrm{Bar}=10 \mu \mathrm{m}$ 


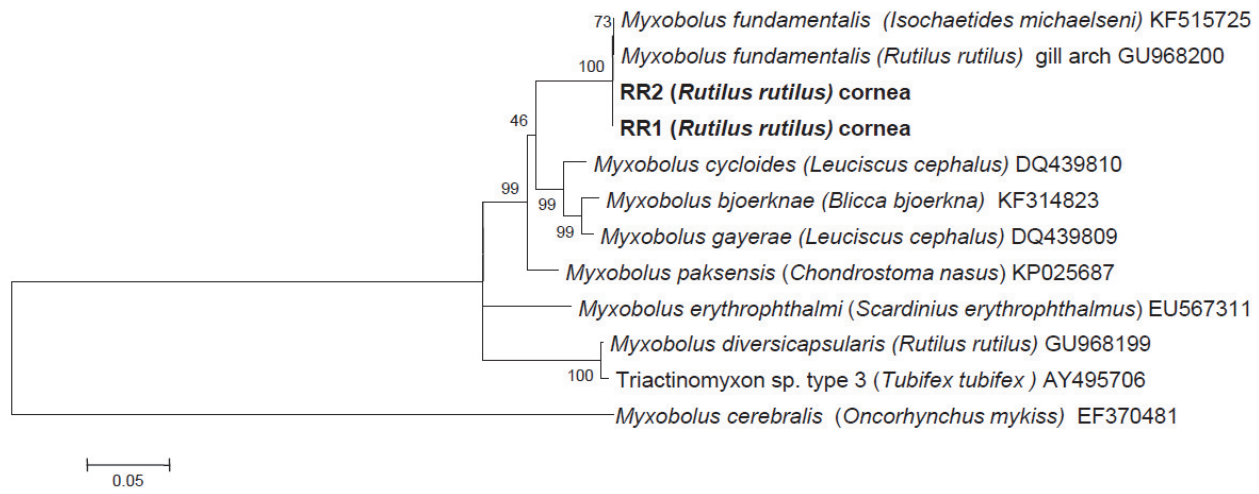

Fig. 5. Phylogenetic position of spores from the cornea of the roach (Rutilus rutilus) based on 18S rDNA analysis by Maximum Likelihood algorithm, GTR $+\mathrm{G}+\mathrm{I}$ model. Myxobolus cerebralis was used as the outgroup. Bootstrap values are given at the nodes. Scale bar indicates the number of expected substitutions per site

\section{Discussion}

Infection of the eye, especially of the corneal layer, by plasmodia of Myxobolus spp. is rather common in different fish species. However, corneal infection of fish in Hungary has so far been reported only in roach. In contrast with the conspicuous signs of infection, the prevalence proved to be rather sporadic during the first study period (2012-2013), but during the targeted examinations conducted in $2017,15 \%$ and $22 \%$ prevalence of infection, respectively, was recorded in the two collection sites (Balatonberény and Balatonboglár) of Lake Balaton in roach specimens. Molecular biological studies revealed that the causative agent of corneal infection corresponded to M. fundamentalis, a specific parasite of the roach, which is known to infect tissues in the basal part of the gill filaments and in the neighbouring connective tissue layer of the cartilaginous gill arch. Despite their different location, these two infection sites of the fish show strong resemblance in their histological structure. Plasmodia develop in the multilayered dense connective tissue of both organs. Molnár (1994) claimed that myxosporeans, especially Myxobolus spp., have a relatively strict host, tissue and organ specificity. In our case the specificity of the host (roach) and the tissue (connective tissue) corresponded to the above-mentioned thesis; however, the plasmodia developed in another organ. Similar differences in locations were found by Moshu and Molnár (1997) when studying Thelohanellus nikolskii infection of the common carp. In that case, plasmodia of the above species infected the fins of the fingerlings of common carp but in older fishes they were located in the scales. Plasmodia started their development in the collagenous connective tissue in both cases. Similarly, M. gayerae Molnár et al., 2007 and M. pfeifferi Thélohan, 1895, the parasites of the chub (Squalius cephalus L.) and the barbel 
(Barbus barbus L.), formed plasmodia both in the multilayered dense connective tissue of blood vessels in the gill arch and in the intestinal wall (Molnár et al., 2014). In this study, spores of M. fundamentalis from the cornea and the gill arch corresponded to each other in spore morphology, and in both cases well-developed mature plasmodia were found, suggesting that both locations are suitable places for the development of this parasite. The lack of organ specificity is especially valid for parasites of the connective tissue. Adriano et al. (2009) reported that Myxobolus cordeiroi Adriano et al., 2009, a parasite of Zungaro jahu Ihering, 1898 , infected the connective tissue of various organs in this fish. Although organ specificity is a useful tool for the identification of some myxozoan species, plasmodia developing in tissues like connective tissue, muscles and nerves frequently occur in different parts of the fish body. Therefore, in these cases, organ specificity is a less important factor for the identification of the parasites.

No reliable data are available on the pathogenic effect of myxosporeans causing corneal infection in fish. Muzzal (1995) supposed that young yellow perch specimens may die of infection with $M$. scleropercae. We suppose that even heavy infection with several plasmodia cannot result in the host's death or general destruction of the eye, but damages to the cornea impair the eyesight of the affected fish and increase their chance of being caught by predators.

\section{Acknowledgements}

This study was supported by the GINOP 2.3.2-15-2016-00004 project 'Establishing the sustainable angling-aimed management of Lake Balaton'. The authors express their thanks to Dr György Csaba for making available to them one of his pictures, and to Ms Györgyi Ostoros for the histological work.

\section{References}

Adriano, E. A., Arana, S., Alves, A. L., Silva, M. R., Ceccarelli, P. S., Henrique-Silva, F. and Maia, A. A. M. (2009): Myxobolus cordeiroi n. sp., a parasite of Zungaro jahu (Siluriformes: Pimelodiade) from Brazilian Pantanal: Morphology, phylogeny and histopathology. Vet. Parasitol. 162, 221-229.

Awerinzew, S. (1913): Myxobolus magnus nov. sp. Zool. Anzeig. 42, 75-76.

Cech, G., Borzák, R., Molnár, K. and Székely, Cs. (2015): Three new species of Myxobolus Bütschli, 1882 (Myxozoa: Myxobolidae) infecting the common nase Chondrostoma nasus (L.) in the River Danube. Syst. Parasitol. 92, 101-111.

Cone, D. K., Horner, R. W. and Hoffman, G. L. (1990): Description of Myxobolus corneus (Myxosporea): a new species from the eyes of bluegill from Illinois. J. Aquat. Anim. Health 2, $132-134$.

Eiras, J. C., Molnár, K. and Lu, Y. S. (2005): Synopsis of the genus Myxobolus Bütschli, 1882 (Myxozoa: Myxosporea: Myxobolidae). Syst. Parasitol. 61, 1-46.

Eiras, J. C., Zhang, J. Y. and Molnár, K. (2014): Synopsis of the species of Myxobolus Bütschli, 1882 (Myxozoa: Myxosporea, Myxobolidae) described between 2005 and 2013. Syst. Parasitol. 88, 11-36. 
El-Mansy, A. (2005): Revision of Myxobolus heterosporus Baker, 1963 (syn. Myxosoma heterospora) (Myxozoa: Myxosporea) in African records. Dis. Aquat. Org. 63, 205-214.

Gioia, I., Cordeiro, N. D. S. and Artigas, P. D. T. (1986): Henneguya intracornea n. sp. (Myxozoa, Myxosporea), an eye parasite of the lambari, Astyanax scabripinis (Jenyns, 1842) (Osteichthyes, Characidae) [in Portuguese, with English abstract]. Mem. Inst. Oswaldo Cruz 81, 401-407

Hemananda, T., Mohilal, N., Bandyopadhyay, P. K. and Mitra, A. K. (2009): Two new Myxosporidia (Myxozoa: Myxosporea) of the genus Myxobolus Bütschli, 1882 from cornea of Clarias batrachus (Linnaeus, 1758) caught from a fish farm in India. North-West. J. Zool. 5, $165-169$.

Li, L. and Desser, S. S. (1985): The protozoan parasites of fish in two lakes of Algonquin Park, Ontario. Can. J. Zool. 61, 1846-1858.

Liu, X. H., Voronin, V. N., Dudin, A. S. and Zhang, J. Y. (2016): Morphological and molecular characterization of Myxobolus mucosus sp n. (Myxosporea: Myxobolidae) with basifilamental sporulation in two cyprinid fishes, Rutilus rutilus (L.) and Leuciscus leuciscus (L.) in Russia. Parasitol. Res. 115, 1297-1304.

Lom, J., Pavlásková, M. and Dyková, I. (1987): Brain thelohanellosis due to Thelohanellus oculileucisci (Myxozoa, Myxosporea) in Gobio gobio._Folia Parasitol. 34, 375-377.

Molnár, K. (1994): Comments on the host, organ and tissue specificity of fish myxosporeans and on the types of their intrapiscine development. Parasitol. Hung. 27, 5-20.

Molnár, K. (2000): Survey on Myxobolus infection of the bleak (Alburnus alburnus L.) in the River Danube and in Lake Balaton. Acta Vet. Hung. 48, 421-432.

Molnár, K. and Eszterbauer, E. (2015): Specificity of infection sites in vertebrate hosts. In: Okamura, B., Gruhl, A. and Bartholomew, J. L. (eds) Myxozoan Evolution, Ecology and Development. Springer, Cham, Heildelberg, New York, Dordrecht, London. pp. 295-313.

Molnár, K. and Székely, Cs. (1999): Myxobolus infection of the gills of common bream (Abramis brama L.) in Lake Balaton and in the Kis-Balaton reservoir, Hungary. Acta Vet. Hung. 47, 419-432.

Molnár, K., Marton, S., Eszterbauer, E. and Székely, C. (2007): Description of Myxobolus gayerae n. sp. and redescription of Myxobolus leuciscine infecting the European chub from the Hungarian stretch of the river Danube. Dis. Aquat. Org. 78, 147-153.

Molnár, K., Marton, Sz., Székely, Cs. and Eszterbauer, E. (2010): Differentiation of Myxobolus spp. (Myxozoa: Myxobolidae) infecting roach (Rutilus rutilus) in Hungary. Parasitol. Res. 107, 1137-1150.

Molnár, K., Székely, Cs., Guti, Cs. F. and Eszterbauer, E. (2014): Two new Myxobolus spp. (Myxozoa: Myxobolidae) from white bream, Blicca bjoerkna (Linneaus, 1758) developing in basifilamental location of gills. Acta Protozool. 53, 277-285.

Moshu, A. and Molnár, K. (1997): Thelohanellus (Myxozoa: Myxosporea) infection of the scales in the European wild carp Cyprinus carpio carpio. Dis. Aquat. Org. 28, 115-123.

Muzzal, P. M. (1995): Distribution of Myxobolus scleroperca (Myxobolidae, Myxosporea) in yellow perch (Perca flavescens) in the Great Lakes. J. Parasitol. 81, 498.

Reuss, R. (1906): Neue Myxoboliden von Susswasserfischen. Bull. L’Acad. Imp. Sci., St. Petersbourg 25, 199-205.

Székely, Cs., Borkhanuddin, M. H., Cech, G., Kelemen, O. and Molnár, K. (2014): Life cycles of three Myxobolus spp. from cyprinid fishes of Lake Balaton, Hungary involve triactinomyxon-type actinospores. Parasitol. Res. 113, 2817-2825.

Tamura, K., Stecher, G., Peterson, D., Filipski, A. and Kumar, S. (2013): MEGA6: Molecular Evolutionary Genetics Analysis version 6.0. Mol. Biol. Evol. 30, 2725-2729.

Thompson, J. D., Higgins, D. G. and Gibson, T. J. (1994): CLUSTAL W: improving the sensitivity of progressive multiple sequence alignment through sequence weighting, position-specific gap penalties and weight matrix choice. Nucl. Acids Res. 22, 4673-4680.

Trojan, E. (1909): Ein Myxobolus im Auge von Leuciscus rutilus. Zool. Anzeig., Leipzig 34, 679-682. 